\title{
Influence of detailing the climate model on the calculation of energy consumption
}

\author{
Elena Malyavina ${ }^{1}$, Olga Malikova ${ }^{1, *}$, and Luong Van Pham ${ }^{1}$ \\ ${ }^{1}$ Moscow State University of Civil Engineering, Yaroslavskoe shosse, 26, Moscow, 129337, Russia
}

\begin{abstract}
The repeatability of outdoor air temperature and enthalpy combinations in a construction area is a necessary initial information for calculating the energy consumption of air conditioning systems. The most convenient form of presenting climatic data in such calculations is the probabilistic-statistical model, which constitutes a Table, the cells of which show the probabilistic repeatability of the outdoor air temperature and relative humidity. The parameter values given on the vertical and horizontal scales, that form the cell boundaries, can be taken with larger or smaller increments. The paper that served as the basis for this article, provides verification of the initial climatic model detailing experimentally under full-scale conditions in the city of Hanoi (Vietnam). The criterion for the appropriate model detailing was the deviation of the energy consumption estimates of the room cooling system, got experimentally and by calculation. Moreover, the calculations were performed not only on two climate probabilistic and statistical models, but also on the data of direct measurements of the outdoor air temperature and relative humidity with an accuracy of $0.1^{\circ} \mathrm{C}$ for temperature and up to $2 \%$ for relative humidity.
\end{abstract}

\section{Introduction}

Much attention is paid to the calculation of energy costs for processing the supply air when designing buildings in different countries [1-6]. In the Russian Federation, the energy consumption by air conditioning systems is considered as a significant one, as well [7-12]. For Hanoi, where air conditioning systems operate in hot and humid climatic conditions of the Central part of North Vietnam, the assessment of energy consumption by these systems is not less important [13-15]. The climate of Hanoi belongs to the tropical monsoon climate. The average summer outdoor temperature is $29.5^{\circ} \mathrm{C}$ raising to $43.7^{\circ} \mathrm{C}$. The hot season starts in mid-April and lasts until mid-September.

The temperature measurement at a weather station is carried out with an accuracy of 0.1 ${ }^{\circ} \mathrm{C}$, and the most accurate measurements of the relative humidity can be made with an accuracy of $2 \%$. Therefore, for two months, the data of the full-scale experiment conditions are presented as three-hour increment measurements by a sequential enumeration of the values of climate indicators with the above accuracy. Based on these data, the calculation of the energy consumption can be considered as the most accurate calculation version.

\footnotetext{
${ }^{*}$ Corresponding author: kryuchkovaou@mgsu.ru
} 
In [16-19] the consistency of the probabilistic statistical climate model was shown as the initial climate information for solving problems in which the process using this data occurs without inertia. Therefore, the article checks the necessary detailing just of this particular model.

The purpose of the proposed work was to compare the energy consumption estimates of an air conditioning system obtained both by a direct experimental measurement and a calculation using two variants of the probabilistic statistical climate model of Hanoi for August and September 2018, which differ in their information detailing. In each model, provision has been made of the frequency of the occurring combinations of the outdoor air temperature and relative humidity. But the Table 1 has cells with gradation by temperature of $2{ }^{\circ} \mathrm{C}$ and relative humidity of $5 \%$, and the Table 2 - by temperature of $1{ }^{\circ} \mathrm{C}$ and relative humidity of $2.5 \%$. For a number of critical objects, the required accuracy of maintaining the parameters of the internal environment is higher than $\pm 2{ }^{\circ} \mathrm{C}$. Therefore, provision should be made of the initial data with smaller scale increments. The PC's capabilities make it possible to perform statistical processing of the initial climatic information in a greater detailing. In addition, the comparison of the results of experimental and calculated data with the direct measurements of the climatic information allowed us to judge the accuracy of the experiment itself. The comparison of the calculation results using two variants of the probabilistic-statistical model, as well as the measured data, expanded the possibilities for an adequate assessment of energy consumption by the room cooling units.

In general, a more elaborated energy consumption estimate of an air conditioning system with the initial climate information provided by the two above described models is due to the refinement of the external borders of the Tables with the considered combinations of the outdoor air temperature and humidity. The fact is that calculations of energy consumption by air conditioning devices are performed for the central point of each cell in the model Table. A Table with smaller cells clarifies the border because the centers of its cells are closer to the real border of possible combinations of the outdoor air parameters.

The second reason for refining the calculations could be a more adequate definition of the boundaries of the transition from one air conditioning unit to another. However, due to the brevity of the experiment, all combinations of the temperature and humidity characteristics required the operation of only the air cooler, which was supposed to cool and dry the indoor air.

\section{Description of the object of research and the methods of the work performance}

In August and September 2018, when the field experiment was performed, the temperature was within $24{ }^{\circ} \mathrm{C}-35^{\circ} \mathrm{C}$, and the relative humidity - of $50 \%-97.5 \%$. The Tables 1 and 2 present climate probabilistic and statistical models during the experiment with different detailing of information.

The field studies have been performed in the office of the Department of "Microclimate and construction environment", at the Hanoi University of civil engineering (NUCE) in Gyai Phong, Hanoi, Vietnam. The room has a plan clean of 7. 8x4. $2 \mathrm{~m}$ and a height of 4.0 $\mathrm{m}$. The area of the room is $32.76 \mathrm{~m}^{2}$, the volume makes $121.21 \mathrm{~m}^{3}$. The total area of the exterior walls is $30.9 \mathrm{~m}^{2}$. The exterior walls are oriented to the East. The total area of the windows is $17.3 \mathrm{~m}^{2}$. 
Table 1. Distribution of repeatability of the outdoor air temperature-relative humidity complex during the working hours from 8 a.m. to 17 p.m. in \% of the total investigation time in August and September 2018 in the Table with large cells.

\begin{tabular}{|c|c|c|c|c|c|c|c|c|c|c|c|c|}
\hline Parameter & \multicolumn{10}{|c|}{ Relative humidity, \% } \\
\hline $\begin{array}{c}\text { Temperatur } \\
\text { e } \\
\text { C }\end{array}$ & $\begin{array}{c}45- \\
50\end{array}$ & $\begin{array}{c}50- \\
55\end{array}$ & $\begin{array}{c}55- \\
60\end{array}$ & $60-65$ & $65-70$ & $70-75$ & $75-80$ & $80-85$ & $85-90$ & $\begin{array}{c}90- \\
95\end{array}$ & $\begin{array}{c}95- \\
100\end{array}$ & total \\
\hline $35-37$ & 0 & 1.82 & 1.09 & 0.364 & 0 & 0 & 0 & 0 & 0 & 0 & 0 & 3.278 \\
\hline $33-35$ & 0 & 1.82 & 2.36 & 6.375 & 4.736 & 0.729 & 0 & 0 & 0 & 0 & 0 & 16.02 \\
\hline $31-33$ & 0.18 & 0.36 & 3.09 & 4.007 & 6.922 & 8.925 & 3.643 & 0.911 & 0 & 0 & 0 & 28.05 \\
\hline $29-31$ & 0.18 & 2.00 & 2.18 & 1.639 & 0.364 & 2.732 & 6.375 & 8.379 & 2.55 & 0.18 & 0 & 26.59 \\
\hline $27-29$ & 0 & 0 & 0.18 & 0.911 & 0.364 & 0.182 & 1.275 & 2.914 & 6.557 & 2.18 & 0 & 14.57 \\
\hline $25-27$ & 0 & 0 & 0 & 0 & 0 & 0 & 0 & 0.182 & 2.186 & 4.37 & 3.097 & 9.836 \\
\hline $23-25$ & 0 & 0 & 0 & 0 & 0 & 0 & 0 & 0 & 0.546 & 1.09 & 0 & 1.639 \\
\hline total & 0.36 & 6.01 & 8.92 & 13.29 & 12.38 & 12.56 & 11.29 & 12.38 & 11.84 & 7.83 & 3.097 & 100 \\
\hline
\end{tabular}

Table 2. Distribution of repeatability of the outdoor air temperature-to-relative humidity complex during the working hours from 8 a.m. to 17 p.m. in \% of the total investigation time in August and September 2018 in the Table with small cells.

\begin{tabular}{|c|c|c|c|c|c|c|c|c|c|c|c|}
\hline Parameter & \multicolumn{10}{|c|}{ Relative humidity, \% } \\
\hline $\begin{array}{c}\text { Temperatu } \\
\text { re, }\end{array}$ & $\begin{array}{c}47.5- \\
50\end{array}$ & $\begin{array}{c}50- \\
52.5\end{array}$ & $\begin{array}{c}52.5- \\
55\end{array}$ & $\begin{array}{c}55- \\
57.5\end{array}$ & $\begin{array}{c}57.5- \\
60\end{array}$ & $\begin{array}{c}60- \\
62.5\end{array}$ & $\begin{array}{c}62.5- \\
65\end{array}$ & $\begin{array}{c}65- \\
67.5\end{array}$ & $\begin{array}{c}67.5- \\
70\end{array}$ & $\begin{array}{c}70- \\
72.5\end{array}$ & $\begin{array}{c}72.5- \\
75\end{array}$ \\
\hline $35-36$ & 0 & 0.729 & 1.093 & 0.729 & 0.364 & 0.364 & 0 & 0 & 0 & 0 & 0 \\
\hline $34-35$ & 0 & 0 & 0 & 0.546 & 1.093 & 1.093 & 1.639 & 0.364 & 0.182 & 0.182 & 0 \\
\hline $33-34$ & 0 & 1.093 & 0.729 & 0.182 & 0.546 & 2.186 & 1.457 & 2.550 & 1.639 & 0.182 & 0.364 \\
\hline $32-33$ & 0 & 0 & 0.364 & 0.911 & 1.457 & 0.729 & 1.275 & 2.186 & 2.550 & 3.825 & 1.275 \\
\hline $31-32$ & 0.182 & 0 & 0 & 0.182 & 0.546 & 0.911 & 1.093 & 1.093 & 1.093 & 2.368 & 1.457 \\
\hline $30-31$ & 0.182 & 0.546 & 0.546 & 0.729 & 0.546 & 0 & 0.364 & 0 & 0.364 & 0.729 & 0.911 \\
\hline $29-30$ & 0 & 0.364 & 0.546 & 0.364 & 0.546 & 0.546 & 0.729 & 0 & 0 & 0.546 & 0.546 \\
\hline $28-29$ & 0 & 0 & 0 & 0 & 0.182 & 0.182 & 0.546 & 0 & 0.182 & 0.182 & 0 \\
\hline $27-28$ & 0 & 0 & 0 & 0 & 0 & 0.182 & 0 & 0.182 & 0 & 0 & 0 \\
\hline $26-27$ & 0 & 0 & 0 & 0 & 0 & 0 & 0 & 0 & 0 & 0 & 0 \\
\hline $25-26$ & 0 & 0 & 0 & 0 & 0 & 0 & 0 & 0 & 0 & 0 & 0 \\
\hline $24-25$ & 0 & 0 & 0 & 0 & 0 & 0 & 0 & 0 & 0 & 0 & 0 \\
\hline total & 0.364 & 2.732 & 3.279 & 3.643 & 5.282 & 6.193 & 7.104 & 6.375 & 6.011 & 8.015 & 4.554 \\
\hline
\end{tabular}

Continuation of the Table 2 (the column with the relative humidity of $72.5-75 \%$ is repeated)

The room under investigation is located on the $7^{\text {th }}$ floor. Similar rooms are located on the $6^{\text {th }}$ and $8^{\text {th }}$ floors. Since the offices with approximately the same microclimate as in the room under investigation are located at the bottom, the top and around it, the heat flows through the floor, the ceiling and the partitions of the room under investigation have been considered to be located within the range of the measurement error. The window of the room under investigation opens into a gallery of $1.89 \mathrm{~m}$ wide, which is a balcony that surrounds the building. The gallery of the overlying floor obscures the study room from direct sunlight. Only scattered radiation enters the room through the window, the flow of which is weakened by the internal window blinds. 
Table 3. Distribution of repeatability of the outdoor air temperature-to-relative humidity complex during the working hours from 8 a.m. to 17 p.m. in \% of the total investigation time in August and September 2018 in the Table with small cells.

\begin{tabular}{|c|c|c|c|c|c|c|c|c|c|c|c|}
\hline Parameter & \multicolumn{10}{|c|}{ Relative humidity, \% } \\
\hline $\begin{array}{c}\text { Temperatu } \\
\text { re, } \\
{ }^{\circ} \mathrm{C}\end{array}$ & $\begin{array}{c}72.5- \\
75\end{array}$ & $\begin{array}{c}75- \\
77.5\end{array}$ & $\begin{array}{c}77.5- \\
80\end{array}$ & $\begin{array}{c}80- \\
82.5\end{array}$ & $\begin{array}{c}82.5- \\
85\end{array}$ & $\begin{array}{c}85- \\
87.5\end{array}$ & $\begin{array}{c}87.5- \\
90\end{array}$ & $\begin{array}{c}90- \\
92.5\end{array}$ & $\begin{array}{c}92.5- \\
95\end{array}$ & $\begin{array}{c}95- \\
97.5\end{array}$ & $\Sigma$ \\
\hline $35-36$ & 0 & 0 & 0 & 0 & 0 & 0 & 0 & 0 & 0 & 0 & 3.279 \\
\hline $34-35$ & 0 & 0 & 0 & 0 & 0 & 0 & 0 & 0 & 0 & 0 & 5.100 \\
\hline $33-34$ & 0.364 & 0 & 0 & 0 & 0 & 0 & 0 & 0 & 0 & 0 & 10.92 \\
\hline $32-33$ & 1.275 & 0.546 & 0 & 0 & 0 & 0 & 0 & 0 & 0 & 0 & 15.11 \\
\hline $31-32$ & 1.457 & 2.186 & 0.911 & 0.911 & 0 & 0 & 0 & 0 & 0 & 0 & 12.93 \\
\hline $30-31$ & 0.911 & 2.186 & 1.457 & 2.368 & 0.911 & 0 & 0 & 0 & 0 & 0 & 11.84 \\
\hline $29-30$ & 0.546 & 1.639 & 1.093 & 2.732 & 2.368 & 2.004 & 0.546 & 0.182 & 0 & 0 & 14.75 \\
\hline $28-29$ & 0 & 0.182 & 0.729 & 0.911 & 1.275 & 3.279 & 0.911 & 0.182 & 0 & 0 & 8.743 \\
\hline $27-28$ & 0 & 0.182 & 0.182 & 0.364 & 0.364 & 1.093 & 1.275 & 1.639 & 0.364 & 0 & 5.829 \\
\hline $26-27$ & 0 & 0 & 0 & 0.182 & 0 & 0.364 & 1.822 & 1.639 & 1.457 & 1.275 & 6.74 \\
\hline $25-26$ & 0 & 0 & 0 & 0 & 0 & 0 & 0 & 0.546 & 0.729 & 1.822 & 3.097 \\
\hline $24-25$ & 0 & 0 & 0 & 0 & 0 & 0 & 0.546 & 1.093 & 0 & 0 & 1.64 \\
\hline total & 4.554 & 6.922 & 4.372 & 7.468 & 4.918 & 6.74 & 5.1 & 5.28 & 2.55 & 3.097 & 100 \\
\hline
\end{tabular}

The parameters of the outdoor air and the solar radiation intensity concerning the measurements made every 3 hours were got from the nearest weather station. During the experiment the following values have been measured with a 1 hour frequency: the temperature of inner and outer surfaces of the exterior wall of the room under investigation; the air temperature and the relative humidity at three points according to the plan and on 4 levels in height; the air temperature and relative humidity at the supply and exhaust grilles in the room; the outdoor air temperature and relative humidity at the air intake (to correct the weather station data); the temperature and the relative humidity of the air that enters and leaves the room indoor cassette cooling unit; the electrical power consumption by the cassette ventilator, supply and exhaust fans of ventilation systems, as well as the electrical power consumption of the outdoor autonomous air conditioning unit (the compressor and the cooling fans).

During the working hours, from 8 a.m. to 17 p.m., the indoor air temperature $t_{B}$ in the room under investigation and the surrounding premises has been maintained within $26.0 \pm$ $1.0^{\circ} \mathrm{C}$.

To maintain a standard heat-humidity microclimate in the room, it has been served by an autonomous direct-cooling air conditioner VRV 10HP. The average cooling coefficient of the device in the EER cooling mode $=3.54$. This unit has 2 inner blocks, one of which is installed in the room under investigation and has the air flow rate of $1350 \mathrm{~m}^{3} / \mathrm{h}$ for the cooler and a cooling capacity of $14.5 \mathrm{~kW}$, and the other inner block serves the adjacent room. The air conditioner internal blocks are the cassette-type ones. The external block of the unit is located in the gallery of the room next to the room under investigation.

The room under investigation is equipped with a direct-flow system of supply and exhaust ventilation, which also serves the adjacent room. To use the exhaust air cold, a VAM800 plate air-to-air recuperator is installed in the system at the inlet after the air intake and before the exhaust air is released into the atmosphere. The total air flow rate for two rooms in the supply and exhaust systems is $800 \mathrm{~m}^{3} / \mathrm{h}$. Moreover, $160 \mathrm{~m}^{3} / \mathrm{h}$ of air is supplied to the study room after the cold recover. The temperature efficiency of the heat exchanger 
is 0.74 . When calculating the required cooling capacity, the ventilation air intakes have been taken into account every hour as the heat and humidity ones.

The following values of heat gains were used in calculating the heat-humidity ratio:

- from people with a total number of 4 persons at the time in question. Under the conditions of a light work and the temperature close to $25^{\circ} \mathrm{C}, 60 \mathrm{~W}$ of the emitted heat and $114 \mathrm{~g} / \mathrm{h}$ of the emitted moisture have been taken per one person;

- from artificial lighting at the real average power of electric fluorescent lamps in the room, equal to $24 \mathrm{~W} / \mathrm{m}^{2}$. The light has been permanently switched on during the working day;

- from the solar radiation directly penetrating the room- by measurements;

- due to the heat transfer through the filling of light openings as a result of the temperature difference and the heating of the glasses by the sun, we determined by calculations taking into account the measured temperature values;

- from the computers, the heat emissions have been taken as $135 \mathrm{~W}$ from each PC and $550 \mathrm{~W}$ of multi-functional devices (MFDs).

The moisture releases only from people.

The number of people present and computers turned on was recorded constantly during the working day for the accounting the heat and moisture emissions in the room. To do this, a log book was created in which all employees noted the time of coming in and leaving the room. In addition, the lighting switching on and off time, as well as the time of using the printers (MFDs), was noted.

From the analysis of heat and moisture gains of the room, it was found that the average value of the heat-humidity ratio in the room during the full-scale experiment is equal to $\varepsilon=8622 \mathrm{~kJ} / \mathrm{kg}$.

\section{Results of calculations and their discussion}

Since the main purpose of the work is to determine the necessarily detailed climatic model, which serves as the initial information for calculating the energy consumption of the system for maintaining the heat-humidity microclimate of the room, it was decided to focus on calculating and identifying from the experiment only the cold consumption necessary for processing the supply air in the air cooling unit.

It should be borne in mind that the outdoor air procedure is as follows: first, the outdoor air is cooled in the recuperator by the exhaust air, the temperature of which is $0.23{ }^{\circ} \mathrm{C}$ higher than in the room working area, and the relative humidity is equal to the humidity in the working area. Then, in the room, due to heat and moisture emissions, the air changes its parameters in accordance with the above-mentioned heat and humidity ratio, acquiring the parameters of the air entering the cassette unit.

The analysis of the data from the Tables 1 and 2 allows us to conclude that during the experiment the device worked only in one mode: cooling the supply air with dehumidification. Even if the original outdoor air had a relative humidity of less than $60 \%$ in the atmosphere, the cooling it from a temperature of $29^{\circ} \mathrm{C}$ or higher to the room air temperature will bring its relative humidity to values above the required ones. The calculation confirmed this.

The results of the calculation and the full-scale experiment are presented in the Table 3.

In Table 3, the second row shows the data discrepancies of each column above the line with the measurement values, and below the line with the calculations for directly measured climate data. Significant differences in the calculation results for the climate models 1 and 2 can be explained by the fact that the upper borders of the models contain combinations of the air temperature and humidity that require the greatest cold consumption. 
Table 4. Cold consumptions for two months of the full-scale experiment according to the measurements and calculations based on initial climatic data of various detailing.

\begin{tabular}{|c|c|c|c|}
\hline The experiment & \multicolumn{3}{|c|}{ Calculations } \\
\hline $\begin{array}{c}\text { By measurement data, } \\
\text { MJ }\end{array}$ & $\begin{array}{c}\text { by direct measurements, } \\
\text { MJ }\end{array}$ & $\begin{array}{c}\text { acc .to model 1, } \\
\text { MJ }\end{array}$ & $\begin{array}{c}\text { acc. to model 2 } \\
\text { MJ }\end{array}$ \\
\hline 6580 & 6195.5 & 6163.4 & 8030.3 \\
\hline$-/ 6.2 \%$ & $-5.8 \% /-$ & $6.3 \% /-0.52 \%$ & $22.0 \% / 29.6 ; \%$ \\
\hline
\end{tabular}

\section{Conclusion}

A greater model detailing is reasonable, since it leads to a practically significant correction of energy consumption for processing the supply air in the room cooling devices.

\section{References}

1. T.N. Aynur, Yu.Hwang, R. Radermaecher. Energ. and Build., 41, Issue 9, 922-929, (2009). https://doi.org//10.1016/i

2. S.R. Mohandes, X. Zhang, A. Mahdiyar, Neurocomputing 340, 55-75 (2019). https://doi.org//10.1016/j.neucom

3. T. Heidrich, A. Alimi, L.Grothues, J. Hesselbach, O.Vunch, Energ. and Build 179, 213-222, (2018). https://doi.org//10.1016/j.enbuild

4. K. Harly, F. Al-Amri. Energy 182, 321-336 (2019). https://doi.org//10.1016/j.e

5. Z. Duan, X. Zhao, Ch. Zhan, X.Dong, H. Chen, Energ. and Build 148, 199-210, (2017). https://doi.org//10.1016/j.enbuild

6. A. A. Sinkevich, T.W. Krauss. Changes in thunderstorm characteristics due to feeder cloud merging. J. Atmos. Res./ V. 142, 124 - 132, (2014). https://doi.org/10.1016/j. atmosres.2013.06.007

7. V. Toporet, E.E. Baimachev, V.S. Ignatiev, Proceedings of Universities. Investment. Construction. Real estate 7(4), 204-212. (In Russian) DOI: 10.21285/2227-2917-20174-204-212

8. S. Tul'skaya, O. Sotnikova, S. Chuikin, Ecology and Industry of Russia 21(5), 28-32, (2017) https://doi.org/10.18412/1816-0395-2017-5-28-32

9. A.P. Tsoy, A.S. Granovskiy, D.A. Tsoy, A.V. Baranenko, Bulletin of the International Academy of cold 3, 3-14, (2019) DOI: 10.17586/1606-4313-2019-18-3-3-14

10. S.N. Osipov, A.V. Zakharenko, E.M. Shirokova, Proceedings of CIS higher education institutions and power engineering associations 62(4), 325-340, (2019) https://doi.org/10.21122/1029-7448-2019-62-4-325-340

11. A.E. Aleshin, A.V. Tsygankov, Herald of Dagestan State Technical University. Technical Sciences 41(2), 34-43, (2016) https://doi.org/10.21822/2073-6185-2016-412-34-43

12. A.V. Nikolaev, Construction and architecture 13, 93-98, (2014) DOI: 10.15593/22249923/2014.13.10.

13. TCVN 5687.2010. Ventilation, air conditioning - Design Standards Vietnam (2010).

14. Trần Ngọc Chấn, Building Publishing, Hanoi (2002) 
15. P. Văn Lương, Viet.ese Ass. of Civ. Env., Hanoi, (2015). http://moitruongxaydung.vn/News/NewsDetail/2062 (in Vietnamese)

16. E.G. Malyavina, O.Yu. Malikova., Springer, Cham. 982, (2019). doi.org/10.1007/9783-030-19756-8_7

17. E.G. Malyavina, O.Yu. Malikova, IOP Publ.. IOP Conf. Series: Mat. Sc. and Eng. 463, (2018). 022065. doi:10.1088/1757-899X/463/2/022065

18. E.G. Malyavina, O.Yu. Malikova., P. Van Lyong, IOP Conf. Ser.: Mat. Sc. and Eng., 365, (2018). 022057 doi:10.1088/1757-899X/365/2/022057

19. E.G. Malyavina, O.Yu. Malikova, IOP Conf. Ser.: Mat. Sc. and Eng. 365, (2018) 022009. doi:10.1088/1757-899X/365/2/022009/ 